\title{
PELATIHAN PERANCANGAN ALAT PERMAINAN EDUKATIF (APE) BERBASIS BAHAN BEKAS UNTUK PENDIDIKAN ANAK USIA DINI (PAUD) SE-SIWALANKERTO SURABAYA
}

\author{
Aniendya Christianna \\ Progra Studi Desain Komunikasi Visual, Fakultas Seni dan Desain \\ Universitas Kristen Petra, Surabaya \\ E-mail: aniendya@peter.petra.ac.id
}

\begin{abstract}
Abstrak: Dibutuhkan suatu terobosan untuk memberdayakan dan mensinergikan semua potensi yang telah ada di masyarakat dalam rangka tercapainya layanan terhadap tumbuh kembang anak secara utuh, menyeluruh dan terintegrasi. Salah satunya media yang sangat mendukung tumbuh kembang anak adalah APE. Alat Permainan Edukatif kini sudah banyak dijual di pasaran dengan harga yang bervariasi.Pada umumnya para penyelenggara pendidikan masih banyak membeli alat-alat permainan sebagai pendukung belajar anak. Hal ini tentu saja akan menumbuhkan budaya konsumtif dan akan melemahkan daya kreativitas dan inovasi para pendidik dalam menyelenggarakan proses belajar yang berkualitas bagi anak. Maka, penulis berupaya mengembangkan suatu kegiatan pelatihan guna mendorong kreatifitas Pengajar/Bunda PAUD untuk merancang APE dari bahan-bahan yang murah dan mudah didapat.
\end{abstract}

Kata kunci: Perancangan, alat permainan edukatif, PAUD, dan bahan bekas.

\begin{abstract}
It takes a breakthrough to empower and synergize all the potential that already exists in society in order to achieve the service to child development as a whole, comprehensive and integrated. One of the very media that support the growth and development of children is EGT. Educative Game Tools now widely sold in the market with varying prices. In general, much of the education providers are still buying game tools to support children's learning. This of course will foster consumptive culture and weaken the educator's ability to be creative and innovative in providing a quality learning for children. Thus, the authors attempt to develop a training activity in order to encourage the creativity of Instructor/Mother of preschool children to design various kind of EGT from cheap and easily obtainable materials.
\end{abstract}

Keywords: Design, educative game tools, preschool children, and scrap materials.

\section{PENDAHULUAN}

Pendidikan anak usia dini merupakan pendidikan yang paling mendasar menempati posisi yang sangat strategis dalam pengembangan sumber daya manusia. Mengingat anak usia dini, yaitu anak yang berada pada rentang usia lahir sampai dengan enam tahun merupakan rentang usia kritis dan sekaligus strategis dalam proses pendidikan yang dapat mempengaruhi proses serta hasil pendidikan pada tahap selanjutnya. Itu artinya periode ini merupakan periode kondusif untuk menumbuhkembangkan berbagai kemampuan fisiologis, kognitif, bahasa, sosioemosional, dan spiritual. Pendidikan adalah hal yang sangat penting untuk diperoleh semua anak karena pendidikan merupakan salah satu modal yang harus dimiliki setiap individu untuk meraih kesuksesan dalam hidupnya.
Keberlangsungan pendidikan bagi setiap warganegara perlu mendapat perhatian yang serius dari berbagai pihak terutama pemerintah. Peran dan tanggung jawab pemerintah terhadap pengasuhan, pendidikan dan pengembangan anak usia dini di Indonesia telah diwujudkan dalam bentuk berbagai kebijakan dan kesepakatan baik dalam lingkup Nasional maupun Internasional [1].

Menyikapi fenomena tersebut maka diperlukan adanya suatu terobosan untuk memberdayakan dan mensinergikan semua potensi yang telah ada di masyarakat dalam rangka tercapainya layanan terhadap tumbuh kembang anak secara utuh, menyeluruh dan terintegrasi. Proses pembelajaran pada anak usia dini hendaknya dilakukan dengan tujuan memberikan konsep-konsep dasar yang memiliki kebermaknaan bagi anak melalui penga- 
laman nyata yang memungkinkan anak untuk menunjukkan aktivitas dan rasa ingin tahu (curiosity) secara optimal 9 [2]. Kemudian menempatkan posisi guru/bunda PAUD sebagai pendamping, pembimbing, serta fasilitator bagi anak. Proses pendidikan seperti ini dapat menyeimbangkan bentuk pembelajaran yang hanya berorientasi pada kehendak guru/bunda PAUD yang menempatkan anak secara pasif dan guru/bunda PAUD menjadi dominan. Kebergantungan anak pada pendidik di awal kehidupannya memang sesuatu yang wajar dan dengan berjalannya waktu ada saatnya anak harus lebih mandiri sehingga perlu adanya keseimbangan antara peran dan pola pengasuhan dari pendidik menjadi lebih demokratis agar anak memiliki kebebasan untuk mengeksplorasi dunia sekitar.

Menurut Sudono [3], dunia pendidikan tingkat kanak-kanak adalah sebuah dunia yang tidak terlepas dari bermain. Salah satu sarana yang menjadi sumber belajar penting bagi anak adalah APE. Alat Permainan Edukatif kini sudah banyak dijual di pasaran dengan harga yang bervariasi. Pada umumnya para penyelenggara pendidikan masih banyak membeli alat-alat permainan sebagai pendukung belajar anak. Hal ini tentu saja akan menumbuhkan budaya konsumtif dan akan melemahkan daya kreativitas dan inovasi para pendidik dalam menyelenggarakan proses belajar yang berkualitas bagi anak. Secara umum banyak para penyelenggara pendidikan yang berpendapat bahwa memperoleh alat pendidikan edukatif dengan cara membeli adalah lebih mudah dan ekonomis. Berdasarkan paparan diatas bahwa alat pendidikan edukatif tidak seharusnya mahal, maka penulis berupaya mencoba mengembangkan dan membuat sebuah alat permainan edukatif yang lebih ekonomis.

\section{ANALISIS KONDISI}

Anak usia dini berada dalam masa keemasan disepanjang rentang usia perkembangan manusia. Masa ini merupakan periode sensitif, selama masa inilah anak secara khusus mudah menerima stimulus-stimulus dari lingkungannya. Dimana usia keemasan merupakan masa dimana anak mulai peka untuk menerima berbagai stimulasi dan berbagai upaya pendidikan dari lingkungannya baik disengaja maupun tidak disengaja. Pada masa inilah terjadi pematangan fungsi-fungsi fisik dan psikis sehingga anak siap merespon dan mewujudkan semua tugas-tugas perkembangan yang diharapkan muncul pada pola perilakunya seharihari. Demikian pentingnya pendidikan anak usia dini, maka para pendidik dituntut mampu dan tanggap dengan proses yang terjadi dari dalam diri anak dan berusaha mengikuti perkembangan anak yang individual. Para pendidik diharapkan mampu mengkreasikan lingkungan dengan materi luas yang beragam dan alat-alat yang memungkinkan anak belajar. Serta memperhatikan laju dan kecepatan belajar dari masing-masing anak. Namun, fakta dan data di lapangan menunjukkan bahwa pendidik PAUD (yang disebut dengan Bunda) memiliki konsep diri yang negatif tentang proses kreatif. Anggapan bahwa bakat sangat mendominasi proses kreatif, membuat pendidik PAUD tidak memiliki cukup keberanian untuk berkarya.

APE banyak tersedia di pasaran, mulai dari toko hingga di dalam mall. Berbagai macam varian APE dijual secara bebas. Namun, kendala harga yang cukup tinggi membuat ketersediaan APE menjadi 'sandungan' dalam proses belajar mengajar. PAUD setempat tidak secara berkala menginventarisasi APE yang ada, sehingga kondisi APE cukup tidak terawat. Anggaran yang disediakan pun terbatas untuk pengadaan APE, sehingga proses belajar mengajar dilakukan dengan sarana dan prasarana yang terbatas. Namun, di lain sisi, bagi PAUD yang memiliki anggaran cukup untuk membelanjakan APE, hal ini menjadi halangan menumbuhkembangkan kreatifitas para pendidik PAUD, untuk membuat suatu APE. Karena pendidik PAUD cukup puas dan bergantung pada ketersediaan APE di pasaran. Sehingga lambat laun, hal ini dapat mematikan kreatifitas para pendidik PAUD untuk berinovasi.

\section{ALAT PERMAINAN EDUKATIF}

Dunia pendidikan tingkat kanak-kanak adalah sebuah dunia yang tidak terlepas dari bermain [4]. Salah satu sarana yang menjadi sumber belajar penting bagi anak adalah APE. APE kini sudah banyak dijual di pasaran dengan harga yang bervariasi. Pada umumnya para penyelenggara pendidikan masih banyak membeli alat-alat permainan sebagai pendukung belajar anak. Hal ini tentu saja akan menumbuhkan budaya konsumtif dan akan melemahkan daya kreativitas dan inovasi para pendidik dalam menyelenggarakan proses belajar yang berkualitas bagi anak. Secara umum banyak para penyelenggara pendidikan yang berpendapat bahwa memperoleh APE dengan cara membeli adalah lebih mudah dan ekonomis. Berdasarkan paparan diatas bahwa APE tidak seharusnya mahal, maka penulis berupaya mencoba mengembangkan dan membuat sebuah $\mathrm{APE}$ yang lebih ekonomis.

Menurut Rohani [5], APE adalah permainan yang sengaja dirancang secara khusus untuk kepentingan pendidikan, sekaligus alat permainan yang 
dirancang untuk tujuan meningkatkan aspek-aspek perkembangan anak usia dini [4]. Lebih jauh, APE merupakan semua bentuk permainan yang dirancang untuk memberikan pengalaman pendidikan atau pengalaman belajar kepada para pemainnya, termasuk permainan tradisional dan modern yang diberi muatan pendidikan dan pengajaran. Dengan demikian, tidak menjadi soal apakah permainan itu merupakan permainan asli yang khusus dirancang untuk pendidikan ataukah permainan lama yang diberi nuansa atau dimanfaatkan untuk pendidikan.

Pendeknya, APE merupakan alat-alat permainan yang dirancang dan dibuat untuk menjadi sumber belajar anak-anak usia dini agar mendapatkan pengalaman belajar. Pengalaman ini akan berguna untuk meningkatkan aspek-aspek perkembangan anak yang meliputi aspek fisik/motorik, emosi, sosial, bahasa, kognitif dan moral.

Pada prinsipnya APE meliputi: Pertama, proses mengaktifkan alat indra secara kombinasi sehingga dapat meningkatkan daya serap dan daya ingat anak didik. Kedua, mengandung kesesuaian dengan kebutuhan aspek perkembangan kemampuan dan usia anak didik sehingga tercapai indikator kemampuan yang harus dimiliki anak. Keempat, memiliki kemudahan dalam penggunaannya bagi anak sehingga lebih mudah terjadi interaksi dan memperkuat tingkat pemahamannya dan daya ingat anak. Kelima, membangkitkan minat sehingga mendorong anak untuk memainkannya. Keenam, memiliki nilai guna sehingga besar manfaatnya bagi anak. Dan ketujuh, bersifat efisien dan efektif sehingga mudah dan murah dalam pengadaan dan penggunaannya.

APE memiliki beberapa fungsi penting, antara lain, (1) Membantu dan mendukung proses pembelajaran anak didik agar lebih baik, menarik dan jelas. (2) Mengembangkan seluruh aspek perkembangan anak. (3) Memberi kesempatan pada anak didik memperoleh pengetahuan baru dan memperkaya pengalamannya dengan berbagai alat permainan. (4) Memberi kesempatan pada anak didik untuk mengenal lingkungan dan mengajarkan pada anak untuk mengetahui kekuatan dirinya. (5) Memperjelas materi yang diberikan pada anak. Dan (6) Memberikan motivasi dan merangsang anak untuk melakukan eksplorasi dan bereksperimen dalam peletakan dasar ke arah pertumbuhan dan mengembangkan bahasa, kecerdasan, fisik, sosial dan emosional anak [6].

\section{PELAKSANAAN KEGIATAN}

Kegiatan perancangan perancangan APE untuk pengajar PAUD dilaksanakan selama satu (1) semester, terhitung sejak disetujuinya proposal pengajuan kegiatan, yakni Januari 2013 sampai dengan Juni 2013. Kegiatan perancangan APE disesuaikan dengan kebutuhan PAUD, yakni merujuk pada tema pelajaran selama satu semester. Dan konsultasi setiap minggunya pada pengajar PAUD.

Untuk membekali diri dalam melaksanakan proses perancangan APE, yang harus diperhatikan adalah setiap pembuatan APE haruslah mengikuti kriteria yang sesuai dengan tingkat perkembangan anak. Usaha Bunda PAUD adalah faktor yang utama, dimana mampu merencanakan, mempersiapkan, melaksanakan dan mengevaluasi kegiatan dan manajemen waktu; mengatur penempatan semua peralatan dan perabotan yang akan digunakan sesuai dengan kebutuhan (sesuai dengan kurikulum dan tingkatan kelas) dan keamanannya; setiap APE yang dirancang harus memiliki tingkatan kesulitan yang berbeda dan bervariasi; serta mampu melatih kemandirian anak melalui APE. Pengajar/ guru/bunda PAUD PAUD juga didorong untuk mempersiapkan bahan secara mandiri dan kreatif. Bahan yang digunakan untuk membuat APE harus memperhatikan keamanan bagi peserta didik, seperti kayu (tidak berserat, dapat dicat dengan cat non toxic dan diamplas), busa, tekstil, kardus, bambu, tali, pelepah (pisang, papaya, pinang), biji-bijian, daun kering, raffia, karet, kulit, kapuk, kartun dan kertas bekas. Karena menjaga keselamatan, kesehatan dan keamanan anak merupakan persyaratan utama.

Agar media yang dirancang sesuai dengan kebutuhan, maka langkah-langkah yang harus ditempuh untuk menyerap kebutuhan komunitas sasaran melalui proses: Menganalisis kurikulum dan aspek pengembangan anak PAUD, menginventarisasi APE yang ada dan mengidentifikasi kebutuhan, menyimpulkan APE yang dibutuhkan, merencanakan pembuatan rancangan, Menyiapkan bahan, alat dan desain, proses perancangan APE serta konsultasi dan evaluasi. Usai langkah-langkah tersebut dijalankan dan memperoleh kesimpulan kebutuhan target sasaran, maka selanjutnya adalah menetapkan langkah-langkah perancangan APE yang meliputi: pertama, tema APE; kedua, bahan dan APE; ketiga, cara Pembuatan APE; keempat, cara Penggunaan APE; dan kelima, aspek yang dikembangkan berdasarkan simulasi dan evaluasi.

Dikarenakan sudah banyak APE yang telah dikembangkan di pasaran maka tentu saja para guru/bunda PAUD PAUD dengan mudah bisa memilih jenis-jenis APE yang sesuai dengan kebutuhan dan aspek perkembangan anak. Namun 
tidak semua APE tersedia dan terjangkau, karena sebagian besar APE harus dibeli di toko-toko dengan harga yang cukup tinggi.

Berdasarkan langkah-langkah tersebut, rencana tema APE yang akan dirancang adalah kebutuhan selama satu (1) semester, Juli sampai dengan Desember. Tema diputuskan berdasarkan pertimbangan proses pengerjaan APE adalah Januari sampai dengan Juli. Dengan demikian, hasil perancangan APE dapat diaplikasikan dan digunakan ketika memasuki semster baru sekaligus tema baru. Dari sekian tema selama satu semester, hanya beberapa tema yang akan diadakan pelatihan perancangan, dikarenakan keterbatasan waktu dan dana yang disediakan. Meski demikian, diharapkan kegiatan ini dapat menjadi kegiatan percontohan sekaligus mendorong kreatifitas pengajar PAUD.

Ada pun tema yang akan dirancang antara lain: KELUARGAKU (Bulan Agustus minggu ke IV-V), RUMAH (Bulan September minggu ke VI), PAKAIAN (Bulan Oktober minggu ke IX), BINATANG (Bulan Nopember minggu ke XII-XIV), dan TANAMAN (Bulan Nopember sampai dengan Bulan Desember minggu ke XV-XVII).

Pembuatan APE merupakan suatu kegiatan yang memerlukan bekal kemampuan yang memadai. Bekal kemampuan yang dimaksudkan adalah pengetahuan dan keterampilan bagaimana melakukannya sesuai dengan persyaratan-persyaratan tertentu sehingga APE yang dibuat betul-betul efektif dalam mengembangkan aspek-aspek perkembangan anak. Jika Bunda PAUD telah memahami berbagai persyaratan pembuatan APE, selanjutnya guru/bunda PAUD harus memahami bagaimana prosedur pembuatan APE. Prosedur pembuatan APE itu sendiri dapat dilakukan dengan mengikuti langkah-langkah sebagai berikut:

a) Bunda PAUD mengkaji dan memahami karakteristik anak didiknya. Jika guru/bunda PAUD akan membuat APE, maka guru/bunda PAUD perlu terlebih dahulu memahami karakteristik anak yang menjadi sasaran pembuatan APE yang dilakukan guru/bunda PAUD. Setiap anak pada hakekatnya mempunyai karakteristik yang berbeda-beda, maka guru/bunda PAUD perlu menentukan secara khas siapa sesungguhnya anak yang akan di layani dengan APE tersebut.

b) Bunda PAUD menelaaah program kegiatan dan tujuan belajar anak. Langkah selanjutnya yang harus diperhatikan guru/bunda PAUD dalam pembuatan APE adalah menelaah program kegiatan dan tujuan belajar anak. Program kegiatan dan tujuan belajar anak yang dimaksud adalah kurikulum yang digunakan di PAUD. Di dalam kurikulum telah secara jelas dan gamblang disajikan mengenai rumusan kemampuan atau kompetensi dan penjabarannya berupa indikator-indikator kemampuan yang harus dicapai atau diperoleh oleh anak.

Rumusan kompetensi dan indikator-indikator yang terdapat didalam kurikulum harus ditelaah dan dipahami oleh guru/bunda PAUD sehingga guru/bunda PAUD memperoleh pemahaman yang utuh mengenai apa saja yang harus dicapai oleh anak PAUD melalui kegiatan belajar dan bermainnya. Dengan pemahaman yang memadai mengenai isi program kegiatan dan tujuan belajar anak akan memudahkan guru/bunda PAUD dalam membuat APE dan disisi lain APE yang dibuat menjadi efektif untuk mengembangkan kemampuan anak.

c) Memilih isi/ tema dan tujuan belajar dari tema tersebut. Langkah berikutnya yang dilakukan guru/bunda PAUD dalam pembuatan APE adalah memilih tema dan yang terdapat di dalam kurikulum atau tema yang dirancang sendiri. Tema adalah alat yang digunakan untuk mencapai berbagai aspek perkembangan anak. Sebenarnya penentuan tema tersebut tidak harus selalu terpaku pada tema-tema yang terdapat di dalam kurikulum, guru/bunda PAUD dapat membuat dan mengembangkan tema sendiri.

d) Menginventarisasi APE yang sudah ada dan menelaah apakah APE tersebut telah sesuai dengan kurikulum atau belum. Proses ini penting dilakukan guru/bunda PAUD sehingga guru/bunda PAUD dapat mengetahui APE apa saja yang sebenarnya sangat penting diadalah dan dibuat oleh guru/bunda PAUD. Seringkali guru/bunda PAUD membuat APE yang sudah ada dan sebenarnya tidak diperlukan lagi sementara yang belum ada terabaikan.

e) Menentukan jenis APE yang akan dibuat dan dikembangkan. Setelah dilakukan inventarisasi terhadap berbagai APE yang telah ada, guru/ bunda PAUD akan mengetahui secara pasti apa saja APE yang dibutuhkan untuk kegiatan belajar anak.

f) Membuat rancangan untuk pembuatan APE. Jika APE yang akan dibuat telah ditentukan maka selanjutnya guru/bunda PAUD membuat rancangan atau desain alat permainan tersebut untuk memudahkan dalam pembuatannya. Dalam rancangan pembuatan APE tersebut biasanya dikemukakan aspek perkembangan anak yang dapat dikembangkan.

g) Menyiapkan alat dan bahan yang diperlukan. Pada tahap berikutnya berdasarkan rancangan yang telah ada, guru/bunda PAUD mempersiapkan alat dan bahan-bahan yang diperlukan sehingga pada saat proses pembuatan tidak 
mengahadapi kendala dan dapat dilakukan sesuai rencana. Ketersediaan alat dan bahan ini akan sangat menunjang pembuatan APE yang dibutuhkan oleh PAUD.

h) Membuat alat permainan sesuai dengan rencana atau sesuai dengan kondisi alat dan bahan yang ada. Pada tahap ini apa yang telah menjadi rencana dilaksanakan dengan mengikuti prosedur pembuatan yang telah ditentukan. Pada tahap ini ide dan rencana dilaksanakan dengan memanfaatkan alat dan bahan yang telah dipilih. Kejelian dan kreativitas guru/bunda PAUD akan sangat mendukung dihasilkannya alat permainan yang benar-benar sesuai dengan kebutuhan PAUD.

i) Memeriksa hasil pembuatan alat permainan, apakah sesuai atau benar telah menghasilkan APE. Setelah guru/bunda PAUD membuat APE tertentu, guru/bunda PAUD masih perlu mengevaluasi apakah APE yang dibuat telah sesuai dengan APE yang diharapkan dalam arti telah memenuhi syarat edukatif, teknis dan estetis. Hal tersebut perlu diperhatikan sebab tidak jarang guru/bunda PAUD yang APE, setelah ditelaah belum menghasilkan APE yang sesuai dengan persyaratan yang ada (standar).
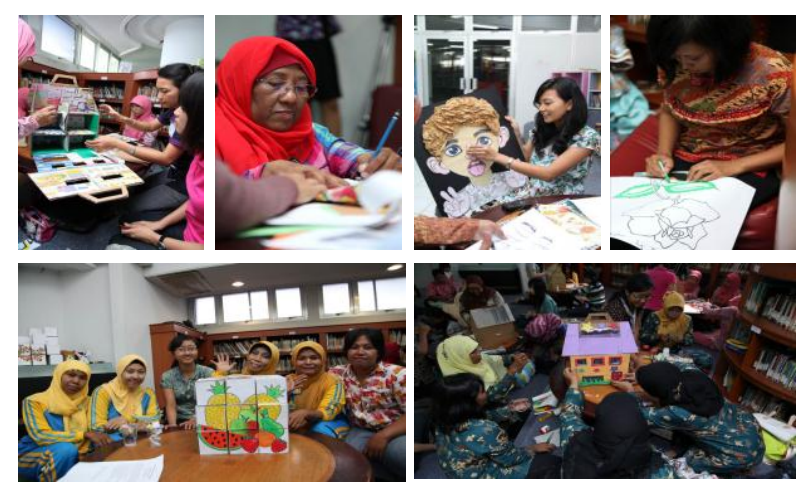

Gambar 1. Dokumentasi Kegiatan pelatihan bersama Bunda

\section{EVALUASI KEGIATAN}

Pelatihan perancangan APE di Siwalankerto diberikan dengan metode ceramah, diskusi, tanya jawab, simulasi/ demonstrasi, redemonstrasi, pembuatan APE dan panduan perancangan APE. pelatihan ini dilaksanakan selama 5 minggu di Pojok Baca Perpustakaan Universitas Kristen Petra Surabaya (lantai 8). Terdapat perwakilan dari masing-masing PAUD dan TBM yang mengikuti pelatihan ini, 3 orang untuk masing-masing PAUD. Dalam pelatihan ini diberikan materi dan konsep-konsep terkait APE sesuai dengan kebutuhan dan kurikulum PAUD. Saat diskusi dan demonstrasi, setiap perwakilan terlibat aktif, mulai dari mengajukan pertanyaan hingga membawa bahan dan per- lengkapan secara mandiri. Kegiatan pelatihan ini disetiap minggunya bersifat kompetitif, diharapkan setiap perwakilan dari PAUD dan TBM termotivasi untuk merancang suatu karya yang menarik. Karena pada akhir acara, akan diberikan hadiah/ kenang-kenangan bagi karya terbaik.

APE yang dibuat di Siwalankerto terdiri dari permainan wayang binatang dari angka, maket rumah, menjahit pakaian, permainan rekat panca indera, dan kubic puzzle. Dimana seluruh karya perwakilan PAUD dan TBM dipamerkan di galeri pameran Perpustakaan Universitas Kristen Petra Surabaya (lantai 6) selama Bulan April 2013. Selain untuk mengapresiasi karya para pengajar PAUD, juga menjadi gaung kampanye ramah lingkungan, dimana sebagian besar perancangan APE menggunakan bahan-bahan bekas.

Sepanjang pelatihan terdapat tim dokumentasi yang merekam langkah-langkah perancangan APE sekaligus mendokumentasi human interest dalam proses pengerjaannya. Pada akhirnya, hasil rekam ini menjadi video Pembelajaran perancangan APE berdurasi kurang lebih 30 menit. Video ini disimpan dalam keping compact disc yang dikemas sedemikian menarik dan diberikan secara cumacuma pada peserta pelatihan. Sehingga peserta pelatihan yang adalah pengajar PAUD dapat menyebarkan informasi perancangan APE ini pada pengajar lainnya di PAUD lainnya. Ataupun ingin membuatnya sendiri di lain waktu melalui tayangan video dan didukung print out panduan cara membuat APE.

Pada dasarnya berbagai alat permainan edukatif diarahkan untuk mencapai tujuan-tujuan sebagai berikut: Pertama, memperjelas materi yang diberikan. Pemanfaatan APE dalam kegiatan belajar anak diharapkan dapat memperjelas materi yang disampaikan oleh guru/bunda PAUD. Sebagai contoh apabila guru/bunda PAUD ingin menjelaskan konsep warna-warna dasar seperti merah, biru, hitam, putih, kuning dan lain sebagainy, jika penyampaian kepada anak hanya secara lisan atau diceritakan, anak hanya sebatas mampu menirukan ucapan guru/bunda PAUD tentang berbagai warna tanpa tahu secara nyata apa yang dimaksud warna merah, kuning dan lainnya. Akan sangat berbeda jika guru/bunda PAUD memanfaatkan APE. Dengan memanfaatkan alat permainan tersebut anak dapat secara langsung melihat, mengamati, membandingkan, memasangkan, dan mengenali berbagai warna. Dengan demikian dapat dimpulkan bahwa dengan memanfaatkan APE selain anak menguasai kemampuan menirukan ucapan guru/bunda PAUD tentang berbagai warna, anak juga mampu menguasai kemampuan yang 
lainnya seperti kemampuan membandingkan berbagai warna karena warna yang satu dengan yang lain berbeda dan kemampuan-kemampuan yang lainnya. Kedua, Memberikan motivasi dan merangsang anak untuk bereksplorasi dan bereksperimen dalam mengembangkan berbagai aspek perkembangannya. Motivasi dan minat anak untuk bereksplorasi dan bereksperimen merupakan faktor penting yang menunjang keberhasilan belajar anak. Oleh karena itu harus dilakukan berbagai upaya sehingga motivasi dan minat anak bisa tumbuh dengan baik. Salah satu upaya yang dapat dilakukan untuk memenuhi hal tersebut adalah dengan memanfaatkan APE. Dan ketiga, memberikan kesenangan pada anak dalam bermain. Apabila diamati, anak yang sedang memainkan alat permainan tertentu dan mereka sangat tertarik untuk memainkannya, mereka tampak sangat serius dan terkadang susah untuk diganggu dan dialihkan perhatiannya pada benda atau kegiatan yang lain. Kondisi tersebut terjadi karena anak-anak merasa senang dan nyaman dengan alat permainan yang mereka gunakan. Alat permainan yang dirancang secara khusus dan dibuat dengan baik akan menumbuhkan perasaan senang anak dalam melakukan aktivitas belajarnya. Jika anak sudah merasa senang dengan kegiatannya, maka belajar tidak lagi dianggap sebagai beban yang ditimpakan guru/ bunda PAUD di pundaknya. Anak mengartikan belajar dengan baik bahwa belajar ternyata tidak selalu dikesankan sebagai kegiatan yang membosankan bahkan menyebalkan tapi justru bermakna dan menyenangkan.

Manfaat yang dapat dipetik oleh komunitas sasaran dengan diadakannya APE antara lain: menambah pengetahuan dan ketrampilan untuk memproduksi APE bagi Bunda PAUD PAUD. Sehingga tidak bergantung pada produk ketersediaan di pasaran. Dengan bahan-bahan yang mudah dan murah, Bunda PAUD PAUD dapat merancang berbagai APE sesuai dengan kebutuhan dan kreatifitas masing-masing. Dengan demikian, ketersediaan medium pengajaran di lembaga pendidikan seperti PAUD, dapat meningkatkan kualitas pembelajaran Pendidikan Anak Usia Dini sehingga memotivasi perkembangan kognitif, daya piki, daya cipta, pisikmotorik, emosi, sosial, dan bahasa Anak Usia Dini.

Menciptakan situasi bermain (belajar) yang menyenangkan bagi anak dan pengajar dalam proses pemberian perangsangan indikator kemampuan anak. Sebagaimana yang telah dikemukakan sebelumnya bahwa kegiatan bermain itu ada yang menggunakan alat, ada pula yang tidak menggunakan alat. Khusus dalam permainan yang menggunakan alat (dalam hal ini APE), anak-anak tampak sangat menikmati kegiatan belajar karena banyak hal yang diperoleh melalui kegiatan belajar tersebut.

Menumbuhkan rasa percaya diri dan membentuk citra diri pengajar PAUD yang positif. Dalam suasana yang menyenangkan, pengajar akan mencoba melakukan berbagai eksperimen kreatif dengan cara menggali dan menemukan kreasikreasi baru. Kondisi tersebut sangat mendukung pengajar PAUD dalam mengembangkan rasa percaya diri dalam perancangan APE berbasis bahan bekas.

Memberikan kesempatan pada para pengajar PAUD untuk bersosialisasi, berkomunikasi dan berbagi ilmu berkesenian. Proses perancangan alat APE ini berfungsi memfasilitasi pengajar PAUD mengembangkan hubungan yang harmonis dan komunikatif dengan lingkungan di sekitar (antar PAUD).

Peningkatan nilai ekonomi bahan bekas bagi para pengajar PAUD dan TB. Wilayah perkotaan yang tak luput dari sampah-sampah rumah tangga, dapat menjadi tantangan sekaligus kesempatan yang baik untuk berkreatifitas (terlebih bernilai ekonomis). Sampah-sampah rumah tangga dan lembaga pendidikan, seperti kertas bekas, posterposter bekas, kardus sisa makanan dan sebagainya berpotensi untuk dikembangkan sebagai usaha kerajinan, pada khususnya perancangan APE. Dengan sentuhan kreatifitas maka sampah-sampah tersebut akan bernilai guna menjadi APE. Kedepan berpotensi menjadi produk APE yang dapat dijual kepada lembaga PAUD dan TK-TK maupun lembaga-lembaga Pendidikan Anak Usia Dini yang lain.

\section{PERAN SERTA DARI KOMUNITAS SASARAN}

Komunitas sasaran adalah pengajar PAUD dan petugas TBM (Taman Baca Masyarakat) seSiwalankerto berperan aktif dalam kegiatan pelatihan perancangan APE ini. Secara mandiri dan kreatif, peserta pelatihan membawa bahanbahan dan perlengkapan guna mendukung proses perancangan karya. Bahkan, bahan-bahan yang jarang ditemui dan harus dibuat secara manual, seperti sampah santan yang dikeringkan, menjadi serbuk kelapa. Kemudian serbuk kelapa yang sudah kering tersebut diberi pewarna makanan, sehingga dapat menjadi salah satu unsur dekorasi pada perancangan APE. Sehingga kesan bertekstur pada karya dapat ditonjolkan. Selain itu, peserta pelatihan juga berinisiatif membawa pelepah pisang, biji-bijian hingga cat poster untuk mendukung tampilan estetis karya APE. 
Selain keterlibatan dalam bahan, peserta pelatihan secara aktif memberi masukan dan kritikan pada setiap ide-ide karya APE, baik dari segi bahan maupun dari tingkat kesulitan. Sehingga, setiap minggu terjadi kemajuan dan perubahan untuk memperbaiki karya APE yang dibutuhkan PAUD.

Secara kuantitas, peserta pelatihan datang tidak saja dari lembaga PAUD, melainkan dari TBM, Taman Kanak-Kanak hingga Perpustakaan Kota Surabaya ikut ambil bagian dalam kegiatan ini. Sehingga kegiatan pelatihan tidak sekedar ceramah dan diskusi, tetapi semakin meriah karena diwarnai sosialisasi dengan komunitas baru. Sehingga terjadi komunikasi dan pertukaran ilmu yang lebih kaya dan variatif dalam rangka mengembangkan APE untuk PAUD.

\section{REKOMENDASI UNTUK KEGIATAN SELANJUTNYA}

Pada akhir kegiatan pelatihan ini, peserta pelatihan mengungkapkan keterbukaan pada pelatihan pelatihan selanjutnya dengan tema dan bahan yang lebih bervariasi. Peserta pelatihan mengungkapkan pula akan menyebarkan informasi yang diperoleh selama pelatihan kepada pengajar PAUD lainnya, dan tidak menutup kemungkinan pada PAUD dan TK lainnya. Sehingga kreatifitas dalam perancangan APE terus berkesinambungan. Bahkan, pengajar PAUD merekomendasikan orang tua peserta didik untuk ambil bagian dalam perancangan APE ini.Sehingga pembelajaran berbasis permainan dapat tetap terlaksana tidak hanya disekolah, tetapi di rumah pun dapat dilakukan.Terlebih bahan-bahan yang digunakan relatif murah dan mudah diperoleh. Direkomendasikan pelatihan perancangan APE yang berbasis nilai ekonomis sehingga dapat menjadi produk APE yang dapat dijual kepada lembaga PAUD dan TKTK maupun lembaga-lembaga PAUD yang lain.

\section{UCAPAN TERIMA KASIH}

1. Tuhan Yesus Kristus.

2. Ketua Pusat Penelitian dan Pengabdian Masyarakat Universitas Kristen Petra Surabaya.
3. Ketua Pengabdian Masyarakat Universitas Kristen Petra Surabaya.

4. Ketua Perpustakaan Universitas Kristen Petra Surabaya..

5. Ketua Program Studi Desain Komunikasi Visual Universitas Kristen Petra Surabaya.

6. Dekan Fakultas Seni dan Desain Universitas Kristen Petra Surabaya.

7. Bapak Tono, Lembaga Penelitian dan Pengabdian Masyarakat Universitas Kristen Petra Surabaya.

8. Bapak Petrus J. Pranowo dan Ibu Dian Wulandari, Perpustakaan Universitas Kristen Petra Surabaya.

9. Bapak Agis Hermansyah, Laboran Audio Visual Desain Komunikasi Visual Universitas Kristen Petra Surabaya.

10. Seluruh Bunda PAUD se-Siwalankerto.

11. Seluruh petugas Taman Baca Masyarakat seSiwalankerto.

12. Unit Kegiatan Mahasiswa (UKM) Dekorasi Universitas Kristen Petra Surabaya.

13. Seluruh Mahasiswa yang berpartisipasi dalam kegiatan Pelatihan Perancangan APE untuk PAUD ini.

\section{DAFTAR PUSTAKA}

[1] Direktorat Pendidikan Anak Usia Dini. 2002. Acuan Menu Pembelajaran pada Taman Penitipan Anak. Jakarta: Direktorat Pendidikan Anak Usia Dini Ditjen PLSP. Depdiknas

[2] Depdiknas. 2001. Program Kegiatan Belajar (Kurikulum) Taman Penitipan Anak. Jakarta: Depdiknas

[3] Sudono, Anggani. 2000. Sumber Belajar dan Alat Permainan (untuk Pendidikan Anak Usia Dini). PT. Grasindo. Jakarta.

[4] WARTA PAUDNI ISSN 1411-1802 Tahun XV Edisi II Tahun 2002.

[5] Ahmad Rohani. 1997. Media Instruksional Edukatif. Rineka Cipta. Jakarta.

[6] Depdiknas. 2001. Pedoman Penyelenggaraan Pendidikan pada Kelompok Bermain. Jakarta: Direktorat Pendidikan Anak Usia Dini. Ditjen PLSP Depdiknas. 